Forthcoming in: Stephany Griffith-Jones, José Antonio Ocampo and Joseph E. Stiglitz (eds.), Time for a Visible Hand: Lessons from the 2008 World Financial Crisis, New York: Oxford University Press. 2009.

\title{
REFORMING THE GLOBAL RESERVE SYSTEM
}

José Antonio Ocampo*

Abstract
The current global reserve system has three fundamental flaws: (1) the deflationary bias
as the burden of adjustment falls on deficit countries; (2) inherent instabilities associated
with the use of a national currency as the major reserve asset and the high demand for
foreign exchange reserves by developing countries, due in turn to pro-cyclical capital
flows and inadequate "collective insurance"; and (3) growing inequities associated with
resource transfers to reserve currency issuing countries. It argues for a system based on
the counter-cyclical issues of Special Drawing Rights (SDRs) that finance IMF facilities,
and some possible "development links" in SDR allocations.

JEL Classification: F02-International Economic Order, F33-International Monetary Arrangements and Institutions, F55-International Institutional Arrangements.

Keywords: Global reserve system, fiduciary dollar standard, financial volatility, foreign exchange reserves, self-protection.

José Antonio Ocampo is Professor, Director of the SIPA Economic and Political Development Concentration and co-President of the Initiative for Policy Dialogue at Columbia University. He was formerly Under-Secretary General of the United Nations for Economic and Social Affairs, Executive Secretary of the Economic Commission for Latin America and the Caribbean, and Minister of Finance of Colombia.

\footnotetext{
* The views expressed in this paper have been enriched by debates that have taken place in the Commission of Experts of the UN General Assembly on Reforms of the International Monetary and Financial System, led by Joseph E. Stiglitz, of which the author is a member (see also in this regard Greenwald and Stiglitz, 2009). I am also grateful to Jomo K.S., Thomas Palley, Lance Taylor, Eduardo Wiesner and John Williamson for comments on a previous draft. The paper draws in part from Ocampo (2007/8). Support from the Ford Foundation is kindly acknowledged.
} 
The magnitude of the ongoing world financial meltdown and its real economic effects has lessened the focus on another set of major international financial issues that had been the center of significant attention in recent years: large global imbalances and their links to the global reserve system. Rising public sector debts and the massive monetary expansion in the United States, coupled with the highly uneven macroeconomic policy stimulus taking place throughout the world are two major reasons why renewed attention has to be paid to these issues.

This chapter analyzes the basic deficiencies that the global reserve system exhibits and its links with global imbalances. It is divided into four sections. The first examines the basic deficiencies of the system. The second and third look in greater detail at the instability and inequities of the system. The last section considers how the reserve system could be reformed.

\section{The deficiencies of the current system}

The global reserve system exhibits three fundamental flaws. All of them are associated with the essential fact that the system lacks mechanisms to guarantee that balance of payments surpluses and deficits (i.e., global imbalances) compensate each other without having adverse effects on world economic activity. Most of the deficiencies generate global deflationary biases but some can also generate inflationary risks. ${ }^{1}$

The first problem, which was highlighted by John M. Keynes during the debates that preceded the creation of the Bretton Woods arrangements, is that the current global monetary system —as all international monetary systems that preceded it-is tilted against deficit countries. This tends to generate a global deflationary bias: the adjustments that deficit countries have to adopt to balance their external accounts, when financing is not available in sufficient amounts (or if those deficits and associated financing are not deemed desirable), will not be matched by expansionary policies in surplus countries, which do not face a similar pressure to adjust. This bias makes itself

\footnotetext{
${ }^{1}$ I will follow the convention of referring to the biases or risks as "deflationary" or "inflationary", although they may affect the level of economic activity rather than the price level, and therefore could rather be called "contractionary" or "expansionary".
} 
felt particularly during periods of generalized balance of payments crises, such as the one we are experiencing today. Since the proposal by Keynes (1942-43) to create a more symmetric system, an International Clearing Union, was not accepted, the Bretton Woods arrangements were born with this intrinsic imperfection. Its very imperfect substitute, the "scarce currency clause," has never been used. We will refer to this problem as the antiKeynesian bias.

The second deficiency, which is generally referred to in the literature as the Triffin dilemma after the pioneering work of Robert Triffin $(1961,1968)$, is associated with the fact that an international reserve system based on a national currency (the U.S. dollar) and, more generally, on a limited number of national or regional currencies (the euro today) - has a built-in instability. The only way for the rest of the world to accumulate net dollar assets is for the U.S. to run a current account deficit. However, U.S. deficits and associated deteriorations in its net external balance sheet tend to erode confidence in the dollar as a reserve currency. This loss may then force adjustments to restore credibility—or, more generally, reverse dollar depreciation—, but this could make the deflationary bias of the system felt.

It must be underscored that, aside from this "exorbitant privilege" (to borrow de Gaulle's characterization of the role of the dollar in the global reserve system) of receiving transfers from the rest of the world (appropriating seignorage powers), its position at the center of the global reserve system gives the U.S. the additional privilege of running a truly independent monetary policy. The basic reason for this is the perception (and consequent use) of U.S. Treasury bills as the "safest assets" in the world economy, which implies that the determinants of U.S. interest rates are relatively independent of the exchange rate of the U.S. dollar against other currencies. This is contrary to what is usually assumed in open macroeconomic models, in which runs on currencies tend to be associated with upward pressures on domestic interest rates, a result that is consistent with the experience of most countries facing balance of payments crises.

The major constraint that the U.S. faced in running an independent monetary policy was the possibility of other countries transforming their dollar reserves into gold, 
but this constraint was lifted in the early 1970s, when the system evolved from the "goldexchange standard" to what is effectively a "fiduciary dollar standard"-and only secondarily a system of competing fiduciary reserve currencies. Given the lack of constraints, we are living in a world in which the monetary policy of the major reserve currency country can alternatively generate excessive liquidity in the international economy or cause contractionary global effects, which make themselves felt during different phases of the business cycle. In this sense, the generation of global liquidity has become even more "capricious” than under the original Bretton Woods system, to use a characterization that was common in the debates of the 1960s. As we will see below, this has been reflected in increasingly intense cycles of the U.S. current account deficits, which have been closely linked with strong fluctuations in the real dollar exchange rate. Furthermore, to the extent that the U.S. does not regard the actual or likely weakening of its currency as a problem to be corrected, the absence of any constraint on U.S. monetary policy implies that, contrary to Keynes' classical views on the deflationary bias of the global reserve system, a fiduciary dollar standard can actually exhibit over certain periods the opposite phenomenon: an inflationary bias. However, although the U.S. is able to spend generously, it does not totally capture the benefits of its expansionary policies, as they are "exported" to the rest of the world through a deterioration in the current account of its balance of payments.

The third deficiency of the current reserve system is that it is inequitable, as the demand for foreign exchange reserves forces developing countries to transfer resources to the countries issuing those reserve currencies-a case of "reverse aid" (see the Zedillo report published as United Nations, 2001). We will refer to this problem as the inequity bias. It has been magnified in recent decades of financial and capital market liberalization by the pressures generated by strongly pro-cyclical flows that developing countries face in world financial markets, which in turn reduce their room to undertake counter-cyclical macroeconomic policies. These facts have led to a massive accumulation of foreign exchange reserves by developing countries as "self-insurance" or, better, "selfprotection” against reversals in capital inflows. This adds up to the more traditional "precautionary" demand for reserves in commodity exporting countries against 
commodity price volatility and, more generally in today's export-led economies, against international trade volatility. ${ }^{2}$

The accumulation of foreign exchange reserves can also be seen as rational responses by individual countries to a system that lacks any well functioning "collective insurance" against balance of payments crises. Furthermore, the fact that the only available collective insurance, International Monetary Fund's (IMF) emergency financing, is deemed unacceptable by many countries due to its conditionalities, actually heightens the demand for self-protection. In this sense, self-protection by developing countries is the demand for foreign exchange reserves associated with both pro-cyclical capital account and trade shocks, and the perception that there are inadequate mechanisms at the global level to provide liquidity to developing countries during balance of payments crises. Although rational from each country's perspective, such protection generates "fallacy of composition" effects that tend to worsen global imbalances and generate deflationary bias in the global system. We will call this problem the inequity-instability link.

Although the inequities of the system were already built into its initial post-war design, they have been considerably heightened since the 1990s by the increased opening of developing countries - trade opening, domestic financial liberalization, and capital account liberalization - and the risks they generated. In fact, the major waves of foreign exchange reserve accumulation followed the two major crises experienced by the developing world - the Latin American debt crisis of the 1980s, and the succession of Asian, Russian and Latin American crises of the late twentieth and early twenty-first centuries - , which made evident that these risks are substantial.

Viewed from the perspective of creditors, pro-cyclicality is obviously a response to the "riskiness" associated with lending to developing countries. What this implies, however, is that this riskiness is not independent of the position these countries occupy in the global economy and in the global reserve system in particular. This is therefore, part of the essential asymmetries of the international economic system - that is, one of its

\footnotetext{
${ }^{2}$ In this regard, Carvalho (2009).
} 
“center-periphery” features, to use a concept that was made popular by Raúl Prebisch half a century ago, and one that is used commonly today, even in mainstream literature.

It is important to emphasize that the three basic problems the current system exhibits would not be solved if several national (or, in the case of Europe, regional) currencies compete for the status of international reserve currencies-which is a secondary feature of the current world monetary system. In particular, although such a multi-reserve currency arrangement would provide developing countries the benefit of diversification of their foreign exchange reserve assets, the seignorage powers would still be concentrated in the industrial countries, so that reverse aid continues to be a feature of the system.

Exchange rate flexibility would allow a full-fledged system of competing reserve currencies to be resilient to the attacks on fixed parities that led to the collapse of both bimetallism in the late nineteenth century and of gold-dollar parities in the early 1970s. However, it adds an additional element of instability to a purely dollar-based system associated with the exchange rate volatility among major reserve currencies—a problem that is already present in the current system. Such volatility results in major gains and losses by central banks on their reserve holding, a feature that increases the risk associated with holding specific reserve assets and, therefore, their value as what they are meant to be: "safe" or low-risk assets. Equally important, if the central banks were to respond to exchange rate fluctuations by changing the composition of their international reserves, this would feed into exchange rate instability. Under these conditions, a full fledged multiple currency reserve system would generate growing calls for a fixed exchange rate arrangement (i.e., a return to a Bretton Woods type scheme, at least among reserve currencies), but fixing the exchange rates among major currencies in a world of large and free capital flows would be a daunting task. It must be added that, given their high demand for foreign exchange reserves, developing countries suffer disproportionally from the instability of the exchange rates of reserve currencies.

In any case, this will continue to be a secondary feature of the system so long as there is no alternative supply of safe assets in the world economy. The bonds of some 
European governments and Japan can be a substitute, but only a partial one, given the size and liquidity of the market for U.S. Treasury bonds. This problem is magnified by the absence of a unified European bond market and the perception by many agents that the euro is backed by a heterogeneous group of countries, with unequal strength.

This implies that the major deficiencies in the current system can only be solved through an overhaul of the global reserve system. Although some other possibilities could be designed—such as Keynes' proposal for an International Clearing Union and similar solutions (see, for example, D’Arista, 1999) ${ }^{3}$ - , the most viable is completing the transition that was launched in the 1960s with the creation of the Special Drawing Rights (SDRs). This implies putting a truly global fiduciary currency at the center of the system, completing a trend towards fiduciary currencies that has been at the center of national and international monetary systems since the nineteenth century (Triffin, 1968). Given the pro-cyclicality of finance towards developing countries, and the high demand for foreign exchange reserves that it generates, this has to be accompanied by reforms aimed at guaranteeing that SDR allocations are used to at least partly correct the problems that developing countries face under the current system.

\section{The Instability of the Global Reserve System}

The cyclical recurrence of U.S. imbalances is closely related to the nature of the current global reserve system. A global deflationary bias was evident in the early postwar period in the form of the "dollar shortage". The gradual accumulation of dollar reserves later generated a pressure on U.S. gold reserves that major countries tried to avoid through the creation of the "gold pool" (Eichengreen, 2007). The failure of this arrangement and the increasingly inflationary bias that the system exhibited, associated with increasing U.S. deficits, led to the abandonment of the gold-dollar parities in the early 1970s. In any case, during the gold-exchange standard, the U.S. generally ran current account surpluses, and the provision of dollar liquidity to the rest of the world was made through the capital account.

\footnotetext{
${ }^{3}$ See also the interesting proposal made in the 1960s to design a commodity-based reserve system, which has interesting counter-cyclical features (Hart, Kaldor and Tinbergen, 1964). I put aside a discussion of a return to a gold standard, which collapsed on its own right and would be unviable under the "embedded liberalism” of the post-Second World War arrangements, as emphasized by Eichengreen (1996).
} 
In contrast, under the fiduciary dollar standard that followed, the current account deficits of the United States have been the rule rather than the exception. The system has also been plagued over the past three and a half decades by an increasingly intense cycle of expansion and contraction in the external deficit of the United States, which has been associated in turn with strong fluctuations of the real exchange rate of the major reserve currency (see Figure 1, and Ocampo, Kregel and Griffith-Jones, 2007, ch. IV). Although real exchange rate fluctuations have played an important role, corrections in the U.S. current account deficit have also been associated with U.S. slowdowns or recessions that have had major effects on the world economy.

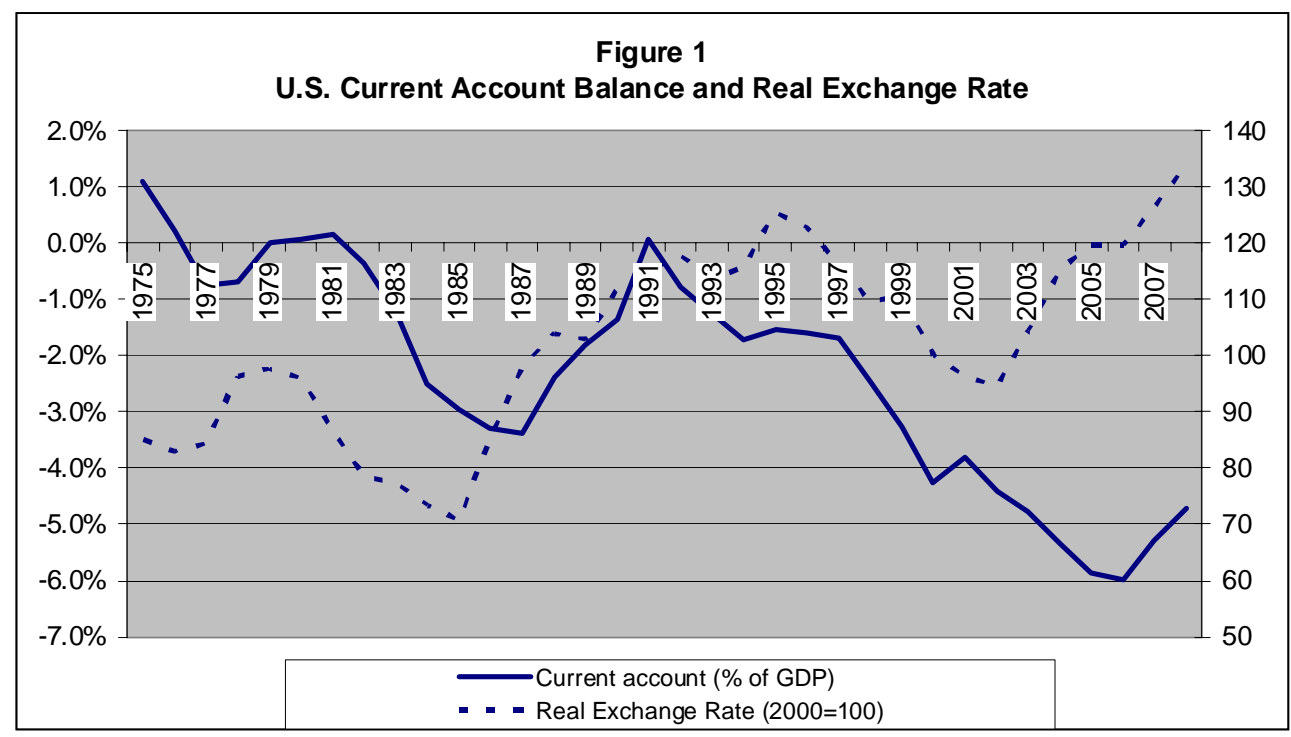

Source: IMF, International Financial Statistics . The real exchange rate is depicted here to show . an increase when there is a real depreciation (the opposite convention to that used by the IMF). It is calculated as the inverse of the real exchange rate estimated by the Fund

The first but short cycle of this type was experienced in the second half of the 1970s: rising deficits in 1977-78 followed by the strong contractionary monetary policy adopted in late 1979, largely to fight inflation which, together with the real depreciation of the dollar, corrected the U.S. deficit but generated a strong global slowdown. A longer and stronger cycle was experienced in the 1980s. During the first half of that decade, contractionary monetary policy, mixed with expansionary fiscal policy later on, led to a substantial appreciation of the U.S. dollar, and a sharp deterioration of the U.S. current account. The adjustment was initiated prior to but was accelerated by the 1985 Plaza 
Accord. The market response produced a sharp real depreciation of the dollar, and led to the Louvre Accord of 1987, which sought to stabilize the dollar. ${ }^{4}$ Following two sharp falls in equity markets, in 1987 and 1989, the correction of the current account deficit was again the joint effect of real exchange rate depreciation and the U.S. recession of the early 1990s. Deterioration of U.S. economic activity led, again, to the global slowdown of 1989-91.

The adjustment of the deficit in the United States during the late 1980s was matched by a rebalancing of surpluses in Germany and a few other developed countries, a number of developing countries in Asia and, as a result of falling petroleum prices, in oilexporting developing countries. In contrast, Japan's large external surplus remained stubbornly high, even though the yen appreciated significantly against the dollar since the mid-1980s. This experience showed that currency appreciation in a surplus country may not necessarily correct external imbalances. The real appreciation may have actually fed into the asset price bubble, which contributed to the financial crisis and stagnation of the Japanese economy during the 1990s; the latter phenomenon in turn swamped the effects of real exchange rate on the current account. ${ }^{5}$

U.S. deficits returned after the 1989-1991 global slowdown but were moderate during the first half of the 1990s. The renewed appreciation of the U.S. dollar in the second half of that decade led to the strongest deterioration of the U.S. current account in history. Although this had its counterpart in a deterioration of U.S. domestic deficits, particularly of households, the large magnitude of the current imbalances also reflects events taking place outside the U.S. economy. Particularly important in this regard was the sharp divergence between U.S. and world economic growth during a conjuncture characterized by recession in many parts of the developing world and the transition economies induced by the Asian, Russian and Latin American crises. As in the past, the strong U.S. and global slowdown of 2001 led to a reduction in the U.S. deficit, but such reduction was very small due to the aforementioned factors.

\footnotetext{
${ }^{4}$ See Frankel (1994) for a detailed account of these development and efforts at international policy coordination during the 1980s.

${ }^{5}$ The preference of China for an orderly appreciation since 2005 seems to be grounded in similar concerns.
} 
The renewed and sharp increase in the U.S. deficit in the early 2000s can be attributed to the joint effect of domestic imbalances and events in the developing world, particularly their very strong demand for self-protection (see next section). The 2003-07 world economic boom was therefore characterized by large current account deficits of the U.S., which continued to widen until 2006, matched by aggregate surpluses in a number of other countries, mainly developing countries in East Asia, commodity-exporting countries in the rest of the world, and Japan. The cumulative depreciation of the dollar since 2003 was strong but orderly. However, it was not accompanied, as in the second half of the 1980s, by a strong correction in U.S. current account deficits. These imbalances only started to fall with the U.S. slowdown of 2007, indicating again that major corrections in the U.S. current account are joint effects of dollar depreciation and U.S. slowdowns, which have global implications.

These trends have changed significantly during the recent global recession. As in previous recessions, the U.S. current account deficit is narrowing. In turn, with the collapse of commodity prices, the surpluses of commodity exporting countries were significantly eroded or washed way. The collapse of world trade has had similar effects on the surpluses of Japan and many East Asian manufacturing exporters, with the major exception of China. Despite the still high current account deficit, the dollar has strengthened in late 2008 and early 2009 due to the "flight to safety" that has accompanied the world financial collapse, and the demand for dollars to finance withdrawals from non-banking financial institutions in the U.S. (an important part of the strong deleveraging process underway). The yen has also been strengthening due to the reversal of Japanese carry trade (a phenomenon similar to the demand for dollars generated by deleveraging), but the major alternative reserve currency, the euro, has shown its incapacity to offer an adequate supply of safe assets.

This short narrative of U.S. imbalances and exchange rates during the three and a half decades under the fiduciary dollar standard indicates also that the role as the center of the global reserve system has had both positive and negative aspects for the United States. On the positive side, the most important advantage is the monetary independence that it confers. The fact that the U.S. is both the global reserve currency and means of 
payments generates a demand for dollar reserves that are usually held in deposits and liquid instruments paying relatively low interest rates, which also enhance the role of the U.S. as the world's banker.

Under the current system, the United States faces an additional advantage. Whereas economies that have external liabilities denominated in other countries' currencies experience a net wealth (real balance) loss when their currencies depreciate, ${ }^{6}$ this effect is absent in the U.S. In contrast, the U.S. experiences a positive wealth (real balance) effect when the dollar depreciates, as such change increases the value of foreign assets owned by U.S. residents, while their liabilities remain invariable. This implies that the depreciation of the U.S. dollar will have weaker effects in terms of rebalancing global current account imbalances, as the wealth effects of such depreciation run counter to the relative price effects (United Nations, 2005, ch. I).

On the negative side, the current account deficit that the U.S. has to incur to provide a net supply of dollar assets to the rest of the world implies that some of the stimulus generated by the expansionary policies of the major reserve issuing country must benefit the rest of the world (Stiglitz, 2006, ch. 9). To the extent that cyclical upswings are also characterized by the appreciation of the U.S. dollar, other countries also gain during theses phases through the increased real value (in terms of their domestic currencies) of assets held in the U.S.

As we have seen, among the three phases of balance of payments imbalances that the U.S. has experienced under the fiduciary dollar standard, the most recent one has been larger in magnitude and has lasted longer. Some analysts have argued that deepening global financial integration has made current imbalances more sustainable. In particular, orthodox analysis has always claimed that in a world of perfect capital markets current account imbalances merely reflect private decisions to allocate savings to the

\footnotetext{
${ }^{6}$ This assumes that these countries (particularly, developing countries) have net liabilities denominated in foreign currencies. Of course, there are agents that profit from depreciation (those with net assets in foreign currencies) as well as losers (agents with net liabilities in foreign currencies). If the country has positive net assets (a characteristic that more developing countries have as the result of the large foreign exchange reserves accumulated in recent years), the real balance effect would be positive, but there will still be distributive effects.
} 
places where it is optimal to invest them. This would imply that current account imbalances are, as such, irrelevant.

Still other analysts have argued that current account imbalances can be sustained for a long time, as the system has evolved into a "Second Bretton Woods" (see Dooley, Folkerts-Landau and Garber, 2003). This school of thought contends that the "mercantilist" decision of the Asian countries to avoid exchange rate appreciation to sustain their export-led growth models implies that they are willing to continue financing U.S. current account deficits. According to this point of view, the economic benefits of stable and weak exchange rates exceed, for those countries, the costs of reserve accumulation (see below).

In contrast to the former views, an increasing number of observers has indicated in recent years that the risks associated with the accumulation of a net U.S. debtor position imply that official and private agents may be unwilling to continue to accumulate dollar assets, due to the possible losses associated with further dollar depreciation (see, for instance, Williamson, 2004). Indeed, the U.S. current account deficits in recent years have been problematic, as they have been financing domestic consumption rather than investment, U.S. investment has been shifting towards nontradable sectors, and the deficit has been increasingly funded by short-term flows rather than direct investment (Summers, 2004). Curiously, these are the same issues that have been raised many times in relation to external imbalances of developing countries, most notably in Latin America.

As the defenders of the Second Bretton Woods hypothesis have recently argued (Dooley, Folkerts-Landau and Garber, 2009), the current crisis has not been accompanied by a run on the dollar. The basic reasons, as we have seen, have been the lack of a large alternative supply of safe assets and the demand for dollars generated by deleveraging. However, this does not imply that the U.S. is safe from a classical balance of payments crisis - that is, a run on dollar assets (including Treasury bills) which will force both dollar depreciation and an increase in U.S. interest rates. The sharp rise in the public sector debt of the United States and the expansion in the balance sheet of the Federal 
Reserve under way add up to the accumulated net external liabilities of the United States to generate risks in that direction.

As we will see below, the desire to run a truly independent monetary and fiscal policy during the current crisis without having to take into account these global implications could actually be a reason why it may be in the interest of the U.S. to move to a non-dollar based reserve system. But even if a classical balance of payments crisis does not take place in the U.S., this does not eliminate the basic deficiencies of the fiduciary dollar standard, which go beyond that specific risk.

\section{The growing inequities of the global reserve system}

The volatility and contagion that characterize financial markets have been demonstrated by a long history of successive phases of "appetite for risk" (or, more accurately, underestimation of risks) followed by periods of "flight to quality" (risk aversion) (Kindleberger, 1978). These boom-bust cycles follow the endogenous unstable dynamics analyzed by Minsky (1982), who argued that financial booms generate excessive risk taking by market agents, which eventually leads to crises. A similar explanation was suggested more recently by White (2005), who underscored how the "search for yield" characteristic of low interest rate environments generates incentives for credit creation, carry trade, and leverage that easily build up asset bubbles. The recent boom-bust cycle in the U.S. and several other countries is a dramatic demonstration of the validity of this view, as are the sharp cycles of financing experienced by the developing world in recent decades. The transmission of shocks, positive and negative, has been enhanced by the liberalization of cross-border capital flows and deregulation of domestic financial markets.

An important feature of contagion is the tendency of markets to cluster countries and firms in certain risk categories. Independently of their objective basis, this clustering becomes a "self-fulfilling prophecy": events that take place in one country or firm tend to be seen as "representative" of an asset class, and therefore tend to generate reactions that affect other members of the cluster. Thus, as the experience of emerging markets indicates, even countries with weak "fundamentals” may be drawn into a financial boom; 
again, with some independence from their fundamentals, they will be later drawn into "sudden stops" of external financing.

The volatility that is inherent in finance is reflected in varying ways in different segments of financial markets. Agents that are perceived to be risky borrowers are subject to the strongest swings in terms of both the availability and costs of financing. Riskier agents include both some domestic agents in industrial countries (e.g., small and medium sized enterprises, poorer households) and emerging markets and, more generally, developing country borrowers. In relation to developing countries, this segmentation of global financial markets is deeply rooted in basic asymmetries that characterize the world economy (Ocampo and Martin, 2003), which in the financial area involve: (i) constraints faced by most developing countries in issuing liabilities in international markets denominated in their own currencies, a phenomenon that has come to be called "original sin” (Eichengreen and Hausman, 2005); (ii) differences in the degree of domestic financial and capital market development, which lead to an under-supply of long term financial instruments in domestic markets; and (iii) the small size of developing countries' domestic financial markets relative to the speculative pressures they potentially face.

The first two asymmetries imply that financial markets are more "incomplete" in developing countries and, as a result, portfolios of market agents are characterized by variable mixes of currency and maturity mismatches. It also implies that some financial intermediation must be conducted through international markets- to the extent, of course, that agents have access to such markets. ${ }^{7}$ A major implication of currency mismatches is that exchange rate fluctuations induced by capital flows (real appreciation during capital account booms, depreciation during crises) generate pro-cyclical wealth effects. Maturity mismatches imply that domestic private and public sectors agents finance long-term investment with short term finance. This means that debtors face

\footnotetext{
${ }^{7}$ This generates an additional set of asymmetries that I will not analyze here. I refer to the fact that poorer countries as well as small firms in all developing countries have very limited or no access to international financial markets. Countries with a poor track record will also have more limited access to these markets.
} 
stronger interest rate risks, and that refinancing requirements associated with debt rotation are high and may lead to bankruptcy during crises.

It is important to note that, although the boom of local currency debt markets that has taken place in the developing world since the Asian crisis partly corrects the original sin, it may just substitute maturity mismatches for currency mismatches. Furthermore, the demand for local currency instruments depends on expectations of exchange rate appreciation, and may therefore lead to outflows when there are expectations of depreciation, as the current crisis has demonstrated. This implies that a more precise definition of original sin should refer to the absence of a stable net demand, in international markets, for assets denominated in the currencies of developing countries. Obviously, domestic agents who do have a permanent demand for assets denominated in developing countries' currencies, also respond in a speculative way to exchange rate expectations.

All of these factors imply that integration of developing countries into global financial markets is always a segmented integration - that is, integration into a market that is segmented by the risk category according to which borrowers are bundled, and one in which high-risk borrowers are subject to strong pro-cyclical swings (Frenkel, 2008). There is, indeed, overwhelming empirical evidence that capital flows to developing countries are pro-cyclical and thus exacerbate rather than dampen both booms and recessions (Prasad et al., 2003).

The volatility that developing countries face includes short-term fluctuations, such as the erratic behavior of short term capital flows, or the very intense upward movement of spreads and the periods of total rationing of financing observed during the Mexican, Asian, and the Russian crises as well as the recent world financial meltdown. Equally important, however, are the medium-term cycles in the availability and costs (spreads) of financing that these countries face. Since the mid-1970s, three full medium-term cycles were experienced: a boom of external financing in the 1970s, followed by a major debt crisis in the 1980s; a new boom in the 1990s, followed by a sharp reduction in net flows after the succession of the Asian and Russian crises of 1997-98; and a new boom since 
2002-03 that had already come to a close in mid-2008, prior to the global financial meltdown of September 2008, which obviously accelerated this process.

Financial asymmetries also generate important macroeconomic asymmetries. In particular, whereas major industrial countries have large room to maneuver to adopt counter-cyclical macroeconomic policies, developing countries face significant constraints to do so (Ocampo, 2008; Stiglitz et al., 2006). There is indeed ample evidence that macroeconomic policies in developing countries are pro-cyclical (Kaminsky, Reinhart and Végh, 2004) and that this pro-cyclical behavior has adverse effects on growth (Ocampo and Vos, 2008, ch. IV).

However, within the limited maneuvering room that these countries have, there is a strong rationale for the adoption of the counter-cyclical macroeconomic policies that are available, aiming either at correcting the direct source of the disturbance, capital account volatility (through capital account regulations) or its macroeconomic effects. Although there have been movements in several policy directions, the most common one during the recent boom was the accumulation of foreign exchange reserves.

The basic rationale for foreign reserve accumulation during booms is to smooth out the effects of pro-cyclical capital flows on exchange rates. If adequately sterilized, such policy makes it possible to target both the exchange rate and the interest rate, thus avoiding (within some limits) the trilemma of open economies (Frenkel, 2007). A similar logic applies to primary commodity exporting countries facing terms of trade shocks. Indeed, saving some of the exceptional export revenues and associated fiscal revenues has long been accepted as a good practice. More generally, to the extent that international trade is pro-cyclical, export booms always have a transitory component. It makes sense therefore to respond to cyclical swings in export revenues by accumulating the excess supply of foreign exchange during booms to be used during the succeeding crises. It is interesting to emphasize, however, that this had not been the practice in the past. Rather, the tendency to overspend capital account as well as trade booms had been the rule rather than the exception. 


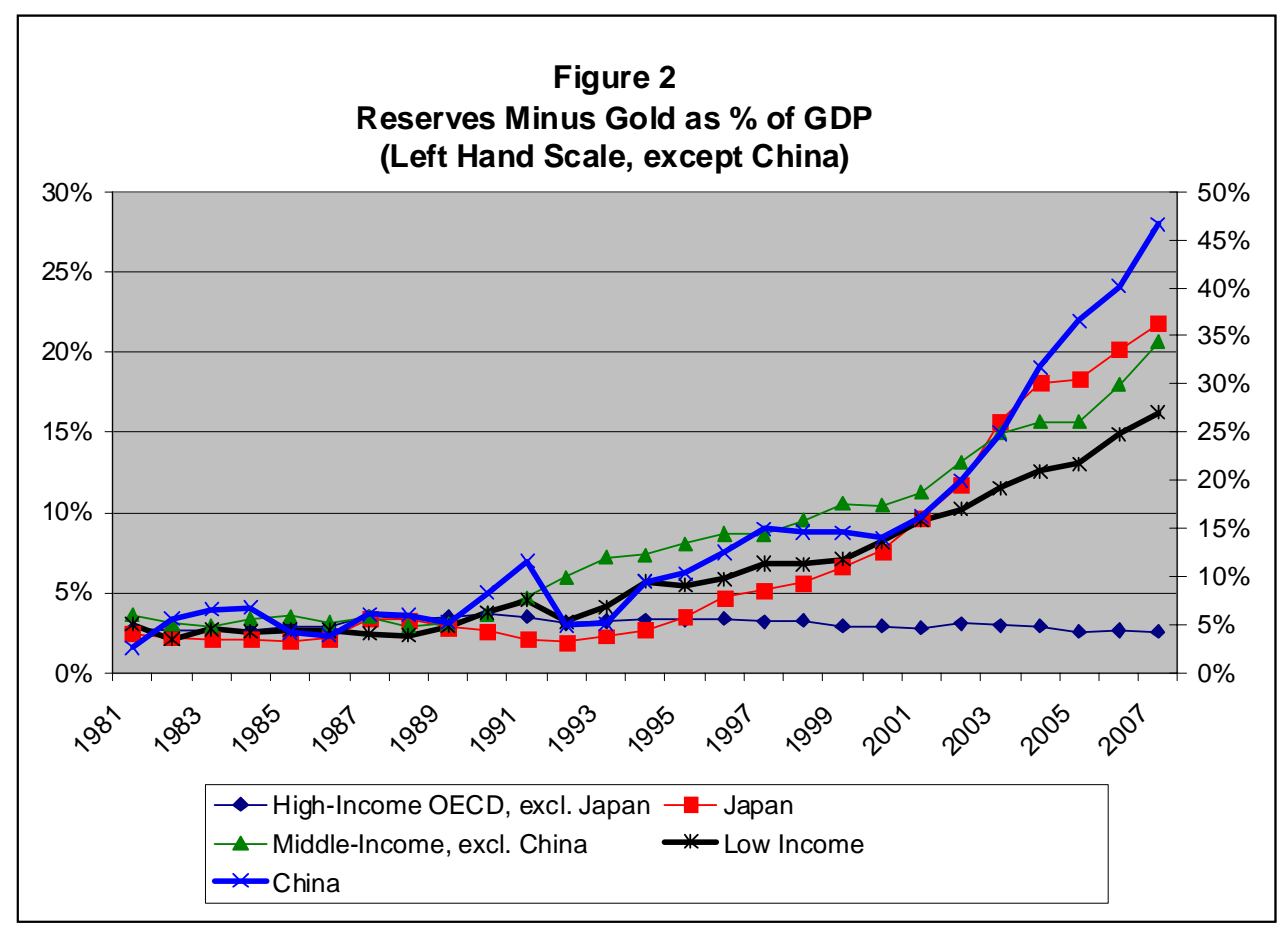

Source: World Bank, World Development Indicators, based on information from IMF.

The very costly crises that developing countries faced in the 1980s and in late 1990s finally led them to use reserve accumulation in an active, in some cases aggressive way. As Figure 2 indicates, up to the 1980s, the demand for reserves by developing countries was not very different from that of the industrial countries, around 3 percent of GDP. Since the 1990s, however, the demand for reserves by developing countries-both middle and low income countries alike — started to diverge radically from that of the industrial world (Japan was the only exception in this regard, as it also joined the reserve boom since the mid-1990s). China was the most aggressive, of course, and had accumulated by 2007 non-gold reserves equivalent to 46.7 percent of its GDP. But middle income countries, excluding China, and low income countries also held in 2007 foreign exchange reserves equivalent to 20.6 and 16.2 percent of GDP, respectively. In contrast, industrial countries excluding Japan only held reserves equivalent to 2.6 percent of GDP, a similar level to that of the 1970s and 1980s. As a result of this trend, the annual additional demand for reserves, which had already increased in the 1990s, skyrocketed during the recent boom: from an annual average of \$111.6 billion in 1991-97 
to $\$ 776.9$ billion in $2003-07$, or from $\$ 75.3$ to $\$ 430.8$ billion if we exclude China and Japan (see Table 1).

\begin{tabular}{|c|c|c|c|c|c|c|c|c|}
\hline & & & ccumulation & $\begin{array}{l}\text { igure } 1 \\
\text { of Foreign Ex }\end{array}$ & lange Reserve & & & \\
\hline & & Million do & & & & $\%$ of $\mathrm{GL}$ & $\overline{\mathrm{DP}}$ & \\
\hline & $1982-90$ & 1991-97 & 1998-02 & 2003-07 & 1990 vs. 81 & 1997 vs 90 & 2002 vs. 97 & 2007 vs. 02 \\
\hline High income: OECD & 42,805 & 30,889 & 59,358 & 140,715 & $0.80 \%$ & $0.08 \%$ & $0.83 \%$ & $0.39 \%$ \\
\hline Japan & 5,588 & 20,164 & 48,307 & 98,320 & $0.18 \%$ & $2.56 \%$ & $6.61 \%$ & $10.00 \%$ \\
\hline Others & 37,217 & 10,725 & 11,051 & 42,395 & $0.94 \%$ & $-0.46 \%$ & $-0.15 \%$ & $-0.47 \%$ \\
\hline High income: non OECD & & 21,833 & 28,554 & 69,822 & & & & \\
\hline Middle income & 6,734 & 56,950 & 63,739 & 548,444 & $0.65 \%$ & $5.58 \%$ & $5.13 \%$ & $12.18 \%$ \\
\hline China & 2,725 & 16,168 & 29,673 & 247,831 & $5.72 \%$ & $6.64 \%$ & $5.04 \%$ & $26.63 \%$ \\
\hline Excluding China & 4,009 & 40,782 & 34,066 & 300,613 & $0.11 \%$ & $4.97 \%$ & $4.49 \%$ & $7.50 \%$ \\
\hline Low income & 212 & 1,952 & 3,654 & 17,938 & $0.76 \%$ & $3.06 \%$ & $3.37 \%$ & $6.04 \%$ \\
\hline World & 59,946 & 111,624 & 155,305 & 776,919 & $0.83 \%$ & $1.43 \%$ & $1.88 \%$ & $4.19 \%$ \\
\hline $\begin{array}{l}\text { Excluding China } \\
\text { and Japan }\end{array}$ & 51,633 & 75,292 & 77,325 & 430,768 & & & & \\
\hline
\end{tabular}

Although reserve accumulation had started after the Latin American crisis of the 1980s, the Asian crisis was the most important turning point. This turning point indicates that the succession of crises, particularly those since 1997, revealed the lack of adequate institutions to manage crises that originated in the capital account, as well as the excessive conditionalities attached to those that are available-i.e., emergency IMF financing. The radical increase in the demand for reserves since the 1990s is, of course, a paradox for those who believe that exchange rate flexibility reduces the demand for reserves. Actually, in the developing world greater flexibility was accompanied by a higher demand for reserves. This made flexible but highly intervened exchange rate regimes quite common in the developing world.

The mercantilist motives of such accumulation have been emphasized by the Second Bretton Woods literature. A reinforcing factor may be the lack of appropriate mechanisms for exchange rate coordination in export-led economies, which generate incentives to keep exchange rates competitive. The idea that weak exchange rates and strong current account balances tend to accelerate economic growth in developing countries has, of course, a respectable tradition in the development literature. ${ }^{8}$

However, the recent literature definitely favors self-protection against capital account volatility as the main motive for foreign exchange reserve accumulation in recent

\footnotetext{
${ }^{8}$ See a survey of this literature in Frenkel and Rapetti (2009).
} 
decades (see, for example, Aizenman and Lee, 2007, and Ocampo, Kregel and GriffithJones, 2007: ch. IV). Indeed, one of the reasons why a strong current account is seen as one of the factors that has positive effects on growth is that it reduces the dependence on the volatility associated with capital flows. If this is the major reason, it would imply that the motivation is really self-protection rather than mercantilism.

The motive for self-protection against financial crises goes beyond the GuidottiGreenspan rule that argues that countries should keep foreign exchange reserves at least equivalent to short-term external liabilities. Indeed, if managing medium-term capital account fluctuations is the most challenging issue, there is a precautionary demand for international reserves that is proportional to total external liabilities, with the proportion actually increasing the more open the capital account is. The recent boom in commodity markets and, more generally, export revenues, also led developing countries to accumulate as foreign exchange reserves a proportion of the additional export revenues. Precautionary demands associated with the expectations that both capital inflows and export revenues had a strong temporary component were therefore behind the rapid rise in reserves in 2003-07.

The pattern of reserve accumulation differs across countries and regions (see also Akyüz, 2009, and Carvalho, 2009). Three types of developing countries can be differentiated in this regard. A first group includes countries with current account deficits for which the only source of reserve accumulation was net capital flows. This is the largest group, and includes whole regions (Central and Eastern Europe, South Asia, and sub-Saharan Africa), including major developing countries such as India, Turkey and Brazil (which ceased to run a current account surplus in the last quarter of 2007), but also a large number of smaller countries. The second group includes countries that mixed current account and capital account surpluses. The major case is China but it also includes several mineral exporters of Latin America. The third are basically energy exporters with strong current account surplus that are net exporters of capital. In any case, the major peaks in reserve accumulation over the past two decades, particularly 2007, are clearly associated with booms in external financing, particularly when China and the 
Middle East are excluded (see Figure 3). ${ }^{9}$ Of course, a significant difference with the previous boom is that, whereas the capital account inflows led to a deterioration in the current account in the 1990s, it did not do so during the recent boom (or did do so, but rather late).

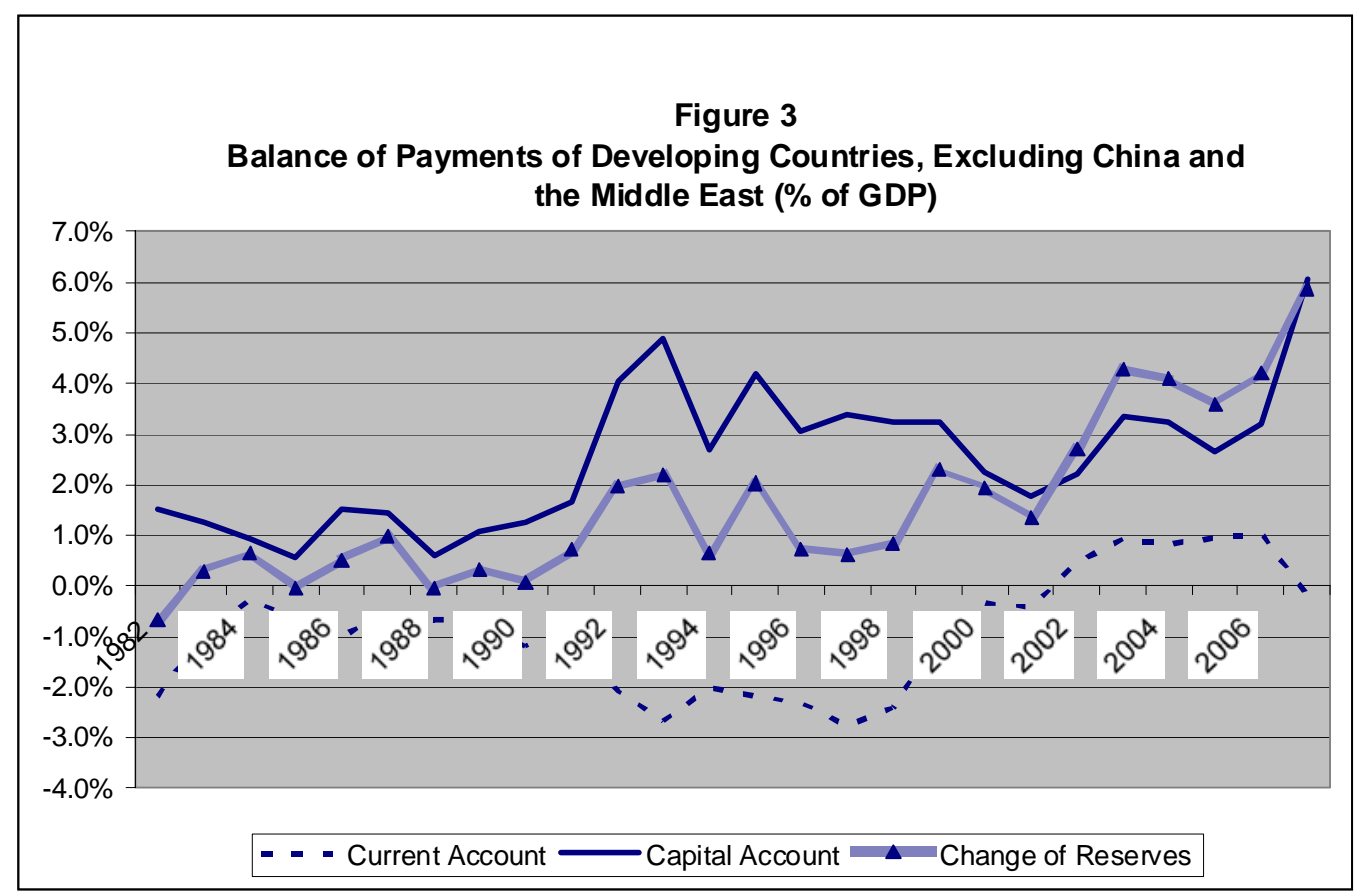

Source: World Bank, World Development Indicators, based on information from IMF.

A third explanation for heavy interventions in foreign exchange markets may be called the "financial stability" motive (Obstfeld, Shambaugh and Taylor, 2008). The major argument is that financially open economies must hold reserves against capital flight, particularly the desire to convert money balances (defined in a broad sense) into foreign exchange. However, it is difficult to separate this demand from that for selfprotection. The fact that reserves tend to be accumulated when there are excess net inflows of capital is the best demonstration that self-protection is the dominant motive.

This behavior raises, of course, some interesting policy questions. From the point of view of the individual countries, the most important is that capital account

\footnotetext{
${ }^{9}$ For this group of countries, whereas the correlation of variation of reserves with net capital flows (both as a proportion of GDP) is 0.715 for the period 1982-2007 as a whole, that between the current account and reserve accumulation is actually negative and not statistically significant $(-0.165)$.
} 
liberalization forces developing countries to absorb net capital inflows in the form of additional foreign exchange reserves - that is, to deepen both sides of the national balance sheet. This is costly and, in a sense, destroys the rationale for capital inflows in the first place, which is to transfer resources from rich to poorer countries. It also implies that the additional rationale for capital account liberalization, to diversify risks, is clearly insufficient, as countries feel in any case that they need the additional self-protection in the form of larger foreign exchange reserves.

For the issue at hand in this paper, what matters, however, is the fact that this strong counter-cyclical rationale generates fallacy of composition effects that feed into global imbalances. Indeed, if a large group of developing countries follows this route, they generate a current account surplus and an additional demand for safe assets that has contractionary effects on the world economy unless it is matched by current account deficits and the supply of those assets by industrial countries.

Therefore, self-protection is not only a costly form of insurance for individual countries (Rodrik, 2006) but is also a source of instability to the global economy. However, the problem cannot be solved simply by asking developing countries to appreciate their currencies to correct their balance of payments surpluses. It must first solve the source of the demand for self-protection, which are strong pro-cyclical capital and trade flows and the lack of adequate supply of collective insurance against balance of payments crises. In the latter case, the problem has many similarities with the instability that a national banking system faced in the past in the absence of a lender of last resort. So, a mix of more active use of capital account regulations and better collective insurance against crises would be the only ways to reduce the strong prudential demand for foreign exchange reserves.

\section{Reforming the system}

The major conclusion of this paper is that the current global reserve system exhibits three fundamental flaws. First, it shows the deflationary bias associated with any system in which all the burden of adjustment falls on deficit countries (the antiKeynesian bias). Second, it is inherently unstable due to two distinct features: the use of a 
national currency as the major reserve asset (the Triffin dilemma) and the high demand for "self-protection" that developing countries face (the inequity-instability link). The latter is related, in turn, to the mix of highly pro-cyclical capital flows and (till now) the absence of adequate supply of "collective insurance" to manage balance of payments crises, which generate a high demand for foreign exchange reserves by developing countries. This implies, third, that the system is inequitable (the inequity bias), and that such inequities have grown as developing countries have accumulated large quantities of foreign exchange reserves.

There could be several potential ways to reform the system, but as pointed out in the first section of this paper, the easiest way would be to complete the expectations of the reforms of the 1960s, when SDRs were created. Obviously, the role of SDRs has changed, particularly in light of the fiduciary dollar standard that arose in the early 1970s. The issues of adequate provision of international liquidity that were at the center of early post-war debates, and were still much in fashion in the 1960s, are not important now, except during extraordinary conjunctures such as those generated during the severe shortage of liquidity created by the world financial collapse of September and October 2008. Actually, as we have seen, the fiduciary dollar standard may actually exhibit an inflationary bias during long periods. However, other problems that were also receiving attention in the 1960s continue to be paramount or are even more important today: particularly, this includes those associated with the composition of world reserves, the access to liquidity by developing countries and associated equity issues. ${ }^{10}$

Any reform effort must considerably increase the size of IMF, which has lagged significantly behind the size of the world economy since the 1998 quota review and relative to world capital flows since the 1970 s. $^{11}$ Note that in this regard, the way the Fund is financed is essential. SDR allocations and quota increases are much better mechanisms than "arrangements to borrow", in their different modalities-the major option chosen in April 2009 by the G-20, as in the past, to make more resources available

\footnotetext{
${ }^{10}$ See good summaries of the debates of the 1960s in Solomon (1977) and Triffin (1968) and an interesting contrast between the role of SDRs then and now in Clark and Polak (2004).

${ }^{11}$ See IMF (2009) and an analysis of different financing options in Truman (2008).
} 
to the Fund during crises. ${ }^{12}$ The quota system could be improved by making contributions exclusively in the currencies of the member countries, thus eliminating the obligation of developing countries to make a fourth of their contribution in SDRs or hard currencies; this would make quotas equivalent to a generalized swap arrangement among central banks. However, the best alternative is to move into a fully SDR-based IMF. As Polak (2005, part II), and Keynes suggested during the debates leading to the creation of the IMF, one advantage of a system based on a truly global reserve currency is that it would eliminate the need for the IMF to manage a multiplicity of currencies, only a small fraction of which (30 percent according to Polak) can be used for IMF lending.

No allocations of SDRs have been made since 1981. The IMF Board of Governors agreed in 1997 on a special one-time allocation, but the associated reform of the IMF Articles of Agreement was not approved by U.S. Congress and therefore the reform has not been made effective. The G-20 made a call in April 2009 to finish this process and make an additional issue of SDRs equivalent to $\$ 250$ billion. The cessation of SDR allocations over more than a quarter century had negative effects for developing countries and the world economy, as it actually coincided with their growing demand for foreign exchange reserves.

Several proposals to renew SDR allocations have been made in recent years, following two different models. The first is issuing SDRs in a counter-cyclical way, concentrating them essentially in periods of world financial stress and possibly destroying them partly once financial conditions normalize (United Nations, 1999; Camdessus, 2000; Ocampo, 2002; Akyüz, 2005). This would develop a counter-cyclical element in world liquidity management, along the lines suggested below. The second model proposes regular allocations of SDRs similar to the additional world demand for reserves, which according to Table 1 is at least $\$ 100-150$ billion a year, if we leave aside the exceptional recent period of reserve accumulation. This is also the magnitude of SDRs that must be issued in the long term under a counter-cyclical rule.

\footnotetext{
${ }^{12}$ On the deficiencies of arrangements to borrow, see Kenen (2001).
} 
Moving into a fully SDR-based IMF with a clear counter-cyclical focus would involve two dimensions. The first would be to make counter-cyclical allocations of SDRs, which would represent, in the traditional terminology, "unconditional” liquidity. The second would involve financing all IMF lending with SDRs. One alternative in this regard is that proposed by Polak (2005, chs. 7-8), according to which IMF lending during crises would actually create new SDRs, similar to how domestic credit by national central banks creates money. SDRs in circulation would in turn be automatically destroyed once such loans are paid for. ${ }^{13}$ The other alternative would be to tie the counter-cyclical issues of SDRs with IMF financing during crises, by treating SDRs that are not used by countries as deposits in (or lending to) the IMF that can be used by the institution to lend to countries in need. ${ }^{14}$ In either of the two options, SDR-funded IMF financing would improve the provision of collective insurance.

For this to work, it is of course essential that IMF credit lines, their conditionality and the stigma associated with borrowing from this institution be overcome, so that countries would actually prefer collective insurance over self-protection. Although there have been recent efforts to improve IMF lending facilities, particularly the March 2009 reforms, it remains to be seen whether they solve these problems. In particular, we still have to see whether the new Flexible Credit Line for crisis prevention purposes would meet the purpose that its predecessors (the Contingency Credit Line and the Short-Term Liquidity Facility) failed to do. This credit line has, as its predecessors, the problem that it unduly divides developing countries in two categories, those with good policies and those with bad policies, which is not only a very unclear division to draw but also generates significant additional risks for the latter. So, it is perhaps time to adopt at least one part of Keynes' original plan for a post-war arrangement: the creation of generous overdraft (or in the terminology of the Fund, drawing) facilities that can be used unconditionally by all IMF members up to a certain cap and for a pre-established time period. Collective insurance would provide both unconditional and conditional lending.

\footnotetext{
${ }^{13}$ There would of course be limits on total lending (the total "quotas" of member states, which would now have a fairly notional sense, except that they would be the basis for SDR allocations and perhaps to determine who bears the costs of running the Fund.

${ }^{14}$ Either of these proposals would involve eliminating the division between what are called the General Resource the SDR Accounts. See Polak (2005, part II) and Cooper (1987), ch. 12.
} 
A major problem that this reform faces is that current IMF quota allocations, which are also the basis for SDR issues and borrowing limits, do not reflect the realities of the world economy today. Aside from the issues that have been discussed in the recent debates on IMF quotas, which have led to some marginal improvements, the even more important issue is the huge disparity in the demand for reserves by developing vs. industrial economies, which are at the center of both the inequities of the current reserve system and the inequity-instability links highlighted in this paper. This problem can be corrected only with either one or a mix of three types of reforms (since they are not mutually exclusive). They should be combined, anyway, with the previous proposals on SDR allocations and SDR-funded collective insurance, which in this sense represent the hard core of the reform proposal.

The first is an asymmetric issuance of SDRs, which would imply that all or a larger proportion of allocations would be given to those countries with the highest demand for reserves-i.e., essentially developing countries.

The second proposal would be to create a clear development link in SDR allocations. One of the proposals on the table is the use of allocation to industrial countries to finance additional aid for the poorest countries and the provision of global public goods (Stiglitz 2006, ch. 9). This proposal has many virtues but poses the problem that such transfers are fiscal in character, and may thus require in every case the approval of national parliaments. The alternative would be a scheme similar to that proposed by the Group of Experts convened by UNCTAD in the 1960s (UNCTAD, 1965), which would allow the IMF to buy bonds from multilateral development banks with the SDRs that are not utilized by member states, which would then finance the demands for longterm resources by developing countries.

The third is encouraging the creation of regional reserve arrangements among developing countries — such as the Latin American Reserve Fund and the Chiang Mai Agreement-that provide a complementary form of collective insurance. A major incentive to the formation of such regional arrangements would be a provision that allocations of SDRs would be proportional not only to IMF quotas but also to reserves 
that developing countries have placed in common reserve funds-thus making pooled reserves equivalent to IMF quotas for this purpose (United Nations, 1999; Ocampo, 2002).

An active use of SDRs with some mix of these features would go a long way to correct the major problems that the current system has, with perhaps one exception: the anti-Keynesian bias. The proposal to put in place Keynes’ overdraft facility is perhaps the best recommendation in that regard. An additional step would be to force all countries to keep a minimum proportion of (or even all) their foreign exchange beyond a certain level in the IMF, again in the form of SDRs. Allocations of SDRs could also be denied to those countries with "excessive reserves." The definition of excessive reserves would have to take into account, of course, the exceptional demand by developing countries for such reserves due to the pro-cyclicality of finance and trade (particularly, but not only, terms of trade) volatility.

The current environment could actually be a good time to introduce these reforms. First, the inflationary risks associated with SDR issues are minimal. ${ }^{15}$ Secondly, the United States has embarked on a large fiscal deficit and an aggressive monetary strategy. This has potential implications for the stability of the current reserve system, as some countries (particularly China) have already indicated. Under the current circumstances, the U.S. might actually find its role at the center of the global monetary system quite uncomfortable, as it could eventually constrain its policy freedom. Also, as indicated above, by giving up its dominant reserve currency status, the U.S. would also free itself from the need to generate current account deficits to provide world liquidity, which have adverse aggregate demand effect on its economy.

In any case, it must be emphasized that giving up the role of the dollar as the major reserve currency would still keep its role as the major international means of payment, unless the SDRs are used in broader financial transactions, as some have suggested in the past (Kenen, 1983; Polak, 2005, part II). Although this is a possibility for the future of the SDRs or an alternative global reserve asset, it is preferable to

\footnotetext{
${ }^{15}$ They are probably minimal even in normal times, as the $\$ 100-150$ billion represent less than 0.2 and 0.3 percent of world GDP, respectively.
} 
concentrate current reforms on enhancing its capacity to serve as a reserve asset, thus limiting its holding to central banks and a few other institutions. The use of the dollar as a means of payments increases the demands for the services of the U.S. financial system, and have other implications for the U.S. that have been explored by other authors (see, for example, Cooper, 1987, ch. 7). It remains to be seen, of course, whether the ongoing financial crisis will have permanent effects on the role of the U.S. as the world's major banker.

The reform of the global reserve system is obviously only part of the reform of the global financial architecture. There are several complementary reforms that can help alleviate some of the problems of the system and strengthen, in particular, the countercyclical dimensions of the global financial architecture. As argued by Ocampo and Griffith-Jones (2008), this should be the essential framework for redesigning such architecture from the perspective of developing countries, and should include a particular emphasis on increasing the "policy space" that these countries have to adopt countercyclical macroeconomic and financial policies.

The first reform is the more active use of capital account regulations, particularly to restrict excessive capital inflows during booms. So, the Fund should be encouraged not only to tolerate but actually advise countries on what regulations to impose under given circumstances. In this regard, the global regulatory structure that would emerge from the crisis should include provisions that apply to cross-border capital movements, such as: generalized reserve requirements on cross-border flows, minimum stay periods, and prohibitions to lend in foreign currencies to economic agents that do not have revenues in those currencies. The second are instruments aimed at better distributing the risk faced by developing countries through the business cycle (GDP-linked or commodity-indexed bonds) or that encourage more stable private flows (such as counter-cyclical guarantees). Thirdly, and very importantly, to avoid the moral hazard issues associated with strengthened IMF emergency financing facilities, a good international debt workout mechanism should be put in place (see, in this regard, Akyüz, 2005, and Herman, Ocampo and Spiegel, 2009). 
Finally, the reform of the global reserve system should be viewed as part of a broader reform aimed at placing the IMF at the center of world macroeconomic policy management. Indeed, such an approach would allow the Fund to go beyond its function as an "emergency financier" of balance of payments crises in the developing world, the essential role that it has played since the mid-1970s. Such reinforcement of the IMF would require strengthening the surveillance of major economies as well as its role as an honest broker in macroeconomic policy coordination, which has been managed through ad-hoc mechanisms since the 1980s (the G-5, then the G-7 and now perhaps the G-20). The multilateral surveillance on global imbalances launched by the Fund in 2006 was an interesting step in that direction, but it lacked binding commitment by the parties and an accountability mechanism.

It must also be emphasized that, despite the problems of representation that the IMF has, which must continued to be addressed, it is the only institution where all member developing countries have a voice, through their constituencies, on global macroeconomic policy issues.

\section{References}

Aizenman, Joshua, and Jaewoo Lee (2007), "International Reserves: Mercantilist vs. Precautionary View, Theory and Evidence.” Open Economies Review. 18:2, April, pp. 191-214.

Akyüz, Yilmaz (2005), "Reforming the IMF: Back to the Drawing Board”, Third World Network, Global Economy Series, No. 7.

(2009), “The Management of Capital Flows and Financial Vulnerability in Asia”, in Stephany Griffith-Jones, José Antonio Ocampo and Joseph E. Stiglitz (eds.), Time for a Visible Hand: Lessons from the 2008 World Financial Crisis, New York: Oxford University Press, forthcoming.

Camdessus, Michel (2000), “An Agenda for the IMF at the Start of the $21^{\text {st }}$ Century”, Remarks at the Council on Foreign Relations, New York, February.

Carvalho, Fernando Cardim de (2009), “The Accumulation of International Reserves as a Defensive Strategy: Reasons and Limitations of Self 'Insurance'”, in Stephany Griffith-Jones, José Antonio Ocampo and Joseph E. Stiglitz (eds.), Time for a Visible Hand: Lessons from the 2008 World Financial Crisis, New York: Oxford University Press, forthcoming. 
Clark, Peter B. and Jacques J. Polak (2004), "International Liquidity and the Role of the SDR in the International Monetary System”, IMF Staff Papers, 51:1, pp. 49-71. Reproduced in Polak (2005), ch. 9.

Cooper, Richard (1987), The International Monetary System: Essays in World Economics, Cambridge, Mass.: MIT Press.

D’Arista, Jane (1999), "Reforming the Privatized International Monetary and Financial Architecture”, Financial Markets and Society, November.

Dooley, Michael P., David Folkerts-Landau and Peter Garber (2003), “An Essay on the Revived Bretton Woods System,” NBER Working Paper, No. 9971, September.

and __ (2009), "Bretton Woods II Still Defines the International Monetary System”, NBER Working Paper, No. 14731, February.

Eichengreen, Barry (1996), Globalizing Capital: A History of the International Monetary System, Princeton: Princeton University Press.

(2007), Global Imbalances and the Lessons of Bretton Woods, Cambridge, Mass.: MIT Press.

and Ricardo Hausmann, eds. (2005), Other People's Money: Debt Denomination and Financial Instability in Emerging Market Economies. Chicago: University of Chicago Press.

Frankel, Jeffrey (1994), “Exchange Rate Policy,” In Martin Feldstein (ed.) American Economic Policy in the 1980s, Chicago: University of Chicago Press, pp.293-341.

Frenkel, Roberto (2007), “The Sustainability of Monetary Sterilization Policies”, CEPAL Review, No. 93, December

(2008), "From the Boom in Capital Inflows to Financial Traps,” in José Antonio Ocampo and Joseph E. Stiglitz (eds.), Capital Market Liberalization and Development, New York: Oxford University Press.

and Martin Rapetti (2009), "Economic Development and the International Financial System”, in Stephany Griffith-Jones, José Antonio Ocampo and Joseph E. Stiglitz (eds.), Time for a Visible Hand: Lessons from the 2008 World Financial Crisis, New York: Oxford University Press, forthcoming.

Greenwald, Bruce and Joseph E. Stiglitz (2009), “A Modest Proposal for International Financial Reform”, in Stephany Griffith-Jones, José Antonio Ocampo and Joseph E. Stiglitz (eds.), Time for a Visible Hand: Lessons from the 2008 World Financial Crisis, New York: Oxford University Press, forthcoming.

Hart, A. G., Nicholas Kaldor and Jan Tinbergen (1964), “The Case for an International Commodity Reserve Currency”, Geneva: UNCTAD. Reproduced in Nicholas 
Kaldor, Essays on Economic Policy II: Vol. IV of Collected Economic Essays, New York: Holmes and Meier, 1980, ch. 18.

Herman, Barry, José Antonio Ocampo and Shari Spiegel, eds. (2009), Overcoming Developing Country Debt Crises, New York: Oxford University Press.

International Monetary Fund (IMF) (2009), "Review of the Adequacy of and Options for Supplementing Fund Resources”, January 12.

Kaminsky, Graciela L., Carmen M. Reinhart and Carlos A. Végh (2004), "When It Rains, It Pours: Procyclical Capital Flows and Macroeconomic Policies," NBER Working Paper No. 10780, September.

Kenen, Peter B. (1983), "Use of SDR to Supplement or Substitute for Other Means of Finance“, in George M. von Furstenberg (ed.), International Money and Credit: The Policy Roles, Washington D.C.: International Monetary Fund, ch. 7.

(2001), The International Financial Architecture: What's New? What's Missing?, Washington D.C.: Institute for International Economics.

Keynes, John M. (1942-43), “The Keynes Plan,” reproduced in J. Keith Horsefield (ed.), The International Monetary Fund 1945-1965: Twenty Years of International Monetary Cooperation, Vol. III: Documents, Washington, D.C.: International Monetary Fund, 1969, pp. 3-36.

Kindleberger, Charles P. (1978), Maniacs, Panics, and Crashes: A History of Financial Crises. New York: John Wiley and Sons.

Minsky, Hyman P. (1982), “The Financial Instability Hypothesis: A Restatement,” in Can "It" Happen Again? Essays on Instability and Finance, Armonk, New York: M.E. Sharpe, ch. 5.

Obstfeld, Maurice, Jay C. Shambaugh and Alan M. Taylor (2008), "Financial Stability, The Trilemma, and International Reserves,” NBER Working Paper 14217. August.

Ocampo, José Antonio (2002), “Recasting the International Financial Agenda,” in John Eatwell and Lance Taylor (eds.), International Capital Markets: Systems in Transition, New York: Oxford University Press, pp. 41-73.

(2007/08), “The Instability and Inequities of the Global Reserve System”, International Journal of Political Economy, Nol. 36, No. 4, Winter.

(2008), “A Broad View of Macroeconomic Stability”, in Narcis Serra and Joseph E. Stiglitz (eds.), The Washington Consensus Reconsidered: Towards a New Global Governance, New York: Oxford University Press. 
and Juan Martin (2003), Globalization and Development: A Latin American and Caribbean Perspective, Palo Alto: Stanford University Press, Economic Commission for Latin America and the Caribbean and World Bank.

Jan Kregel and Stephany Griffith-Jones (2007), International Finance and Development, London: Zed Books.

and Stephany Griffith-Jones (2008), “A Counter-cyclical Framework for a Development-friendly International Financial Architecture”, in José María Fanelli (ed.), Macroeconomic Volatility, Institutions and Financial Architecture: The Developing World Experience, Houndmills: Palgrave/Macmillan.

and Rob Vos (2008), Uneven Economic Development. Hyderabad, London and Penang: Orient Longman, Zed Books and Third World Network.

Polak, Jacques J. (2005), Economic Theory and Financial Policy: Selected Essays of Jacques J. Polak 1994-2004, edited by James M. Boughton, Armonk, NY: M. E. Sharpe.

Prasad, Eswar S., Kenneth Rogoff, Shang-Jin Wei and M. Ayhan Rose (2003), "Effects of Financial Globalization on Developing Countries: Some Empirical Evidence”, Washington D.C.: International Monetary Fund, Occasional Paper 220.

Rodrik, Dani (2006), “The Social Costs of Foreign Exchange Reserves”. International Economic Journal. Vol. 20, No. 3, September.

Solomon, Robert (1977), The International Monetary System 1945-1976: An Insider's View, New York: Harper \& Row.

Stiglitz, Joseph E. (2006). Making Globalization Work, New York: W.W. Norton.

Stiglitz, Joseph E., José Antonio Ocampo, Shari Spiegel, Ricardo Ffrench-Davis and Deepak Nayyar (2006), Stability with Growth: Macroeconomics, Liberalization, and Development, New York: Oxford University Press.

Summers, Lawrence H. (2004), "The U.S. Current Account Deficit and the Global Economy,” Per Jacobson Lecture, Washington D.C.

Triffin, Robert (1961). Gold and the Dollar Crisis (Revised edition). New Haven: Yale University Press.

(1968), Our International Monetary System: Yesterday, Today and Tomorrow, New York: Random House.

Truman, Edwin M. (2008), “On What Terms Is the IMF Worth Funding?”, Working Paper 08-11, Washington, D.C.: Peterson Institute for International Economics. 
UNCTAD (1965), International Monetary Issues and the Developing Countries: Report of the Group of Experts, New York: United Nations.

United Nations (1999), “Towards a New International Financial Architecture: Report of the Task Force of the Executive Committee on Economic and Social Affairs of the United Nations”, http://www.un.org/esa/coordination/ecesa/ecesa-1.pdf.

United Nations (2001), Report of the High-level Panel on Financing for Development (Zedillo Report), www.un.org/reports/financing

United Nations (2005), World Economic Situation and Prospects 2005. New York: United Nations.

White, William R. (2005), "Procyclicality in the Financial System: Do We Need a New Macrofinancial Stabilization Framework?” Kiel Economic Policy Papers. Kiel: Kiel Institute for Economic Policy, September.

Williamson, John (2004), “The Future of the Global Financial System.” Journal of PostKeynesian Economics, 26, no. 4, Summer. 